\title{
Effect of Polyethylene Glycol on Transfection of Escherichia coli Spheroplasts with Bacteriophage $\phi$ X174 Single-stranded and Double-stranded DNAs
}

\author{
Junji MoRita, Tsutomu Nishida and Tohru Komano \\ Laboratory of Biochemistry, Department of Agricultural Chemistry, \\ Kyoto University, Kyoto 606, Japan
}

Received October 18, 1976

\begin{abstract}
The efficiency of transfection of Escherichia coli spheroplasts increased when polyethylene glycol was used as an osmotic stabilizer instead of sucrose. Optimal concentration of polyethylene glycol was 0.5 to $1.0 \%$ for transfection with bacteriophage $\phi \mathrm{X} 174$ single-stranded DNA and 1.0 to $2.0 \%$ for that with $\phi \mathrm{X} 174$ double-stranded replicative form of DNA, and the efficiency of transfection increased 4 to 7 -fold under these conditions. The extent of transfection of the spheroplasts prepared in the presence of polyethylene glycol was proportional to the number of phage DNA added. The effect of polyethylene glycol on transfection was independent of the presence of protamine sulfate.
\end{abstract}

Transfection of Escherichia coli spheroplasts has been used as a effective technique to assay the biological activity of viral nucleic acid. ${ }^{1,2)}$ But, the disadvantage of this system is a low reproducibility for double-stranded DNA and poor stability of the spheroplasts. ${ }^{3)}$ The effect of various substances have been investigated to improve this disadvantage. It have been reported that bovine serum albumin, ${ }^{4,5)}$ protamine sulfate ${ }^{3,6)}$ and spermin ${ }^{6)}$ facilitate transfection with double-stranded DNAs. The effect of DEAE-dextran has been also reported. ${ }^{\text {? }}$ Melechen et al. $^{8)}$ have reported that the efficiency of transfection with bacteriophage $\lambda$ DNA increases by the substitution of polyethylene glycol (PEG) for sucrose as an osmotic stabilizer in the spheroplasts suspension. PEG is a water-soluble, nonionic polymer and used in isolation and purification of macromolecules like nucleic acids and proteins. The effect of a substance on transfection is often depending upon whether nucleic acid used is DNA or RNA, and whether it has double-stranded or single-stranded form. ${ }^{6)}$ We have investigated the effect of PEG on the efficiency of transfection with bacteriophage $\phi \mathrm{X} 174$ singlestranded DNA (ss DNA) and double-stranded replicative-form of DNA (RF DNA). Present results show that $P E G$ facilitates transfection with both $\phi$ X174 ss DNA and RF DNA.

\section{MATERIALS AND METHODS}

Bacteriophages. Bacteriophage $\left.\phi \times 174^{\text {}}\right)$ is a small virus containing single-stranded circular DNA. $\quad \phi X 174$ $a m 3^{10)}$ is a lysis defective amber mutant in gene $\mathrm{E}$.

Bacteria. Escherichia coli $\mathrm{K} 12 \mathrm{~W} 6^{11)}$ was used for spheroplasts preparation. E. coli $\mathrm{C}_{\mathrm{N}}$ g) was used as a host for $\phi \mathrm{X} 174$ multiplication and preparation of RF DNA of $\phi \mathrm{X} 174$ am3. E. coli $\mathrm{HF} 4714^{10)}$ was a suppressor host for $\phi \mathrm{X} 174 \mathrm{am} 3$.

Chemicals. Polyethylene glycol (Carbowax 6000) (PEG) and gelatin were purchased from Nakarai Chemicals Co. Protamine sulfate and lysozyme were purchased from Sigma Chemical Co.

Preparation of DNA. The single-stranded DNA of $\phi \mathrm{X} 174$ ( $\phi \mathrm{X} 174$ ss DNA) was prepared as follows: $\phi \mathrm{X} 174$ was prepared according to the procedure of Sinsheimer, ${ }^{12)}$ purified by using PEG precipitation ${ }^{13)}$ and further purified by a neutral sucrose gradient centrifugation. Fractions having infectivity were combined and dialysed against $0.05 \mathrm{~m}$ borate buffer, $\mathrm{pH} 9.5$. $\phi \mathrm{X} 174$ ss DNA was extracted from purified $\phi \mathrm{X} 174$ particles by the hot phenol method ${ }^{11)}$ and dialysed against $0.05 \mathrm{M}$ Tris- $\mathrm{HCl}, \mathrm{pH} 8.1 . \quad \phi X 174 \mathrm{RF}$ DNA was prepared from $E$. coli $\mathrm{C}_{\mathrm{N}}$ cells infected with $\phi \mathrm{X} 174$ am3 as described previously. ${ }^{14)}$

Preparation of spheroplasts. Spheroplasts of E. coli $\mathrm{K} 12 \mathrm{~W} 6$ cells were prepared by a modification of the method of Guthrie and Sinsheimer. ${ }^{1,11)}$ An amount of $1.3 \mathrm{ml}$ of an overnight culture of $E$. coli $\mathrm{K} 12 \mathrm{~W} 6$, grown in $3 \mathrm{XD}$ medium, ${ }^{11)}$ was transferred to $30 \mathrm{ml}$ of fresh 3XD medium and grown at $37^{\circ} \mathrm{C}$ with aeration to the cell density of $5.0 \times 10^{8}$ cells $/ \mathrm{ml}$. An amount of $25 \mathrm{ml}$ 
of the culture was removed. The cells were collected by a centrifugation at room temperature, washed once with an equal volume of $0.05 \mathrm{~m}$ Tris-HCl-1 mM EDTA, $\mathrm{pH} 8.1$ and resuspended in $0.35 \mathrm{ml}$ of $1.5 \mathrm{M}$ sucrose. The following solutions were added, in order, with gentle mixing after each: $0.255 \mathrm{ml}$ of $20 \%(\mathrm{w} / \mathrm{v})$ gelatin solution, $0.02 \mathrm{ml}$ of lysozyme $(2 \mathrm{mg} / \mathrm{ml}$ in $0.25 \mathrm{M}$ Tris$\mathrm{HCl}, \mathrm{pH} 8.1), 0.04 \mathrm{ml}$ of $4 \%(\mathrm{w} / \mathrm{v})$ EDTA.2Na, $\mathrm{pH} 8.1$, and $10 \mathrm{ml}$ of PA medium ${ }^{11)}$ or PC medium. ${ }^{8)}$ PC medium was the same as PA medium except that sucrose was replaced by PEG. After allowing to stand for $15 \mathrm{~min}$ at room temperature, $0.2 \mathrm{ml}$ of $10 \% \mathrm{MgSO}_{4}$ was added. This suspension was "PA spheroplasts" or "PEG spheroplasts" respectively, stored on ice and assayed for the competence with $\phi \times 174$ ss DNA and RF DNA within $3 \mathrm{hr}$ (transfection assay).

The competence level of PA spheroplasts was the same as that described by Guthrie and Sinsheimer. ${ }^{11)}$

In some experiments, protamine sulfate $(10 \mathrm{mg} / \mathrm{ml}$ in $0.05 \mathrm{M}$ Tris-HCl- $0.5 \mathrm{M} \mathrm{NaCl}, \mathrm{pH} 8.0$ ) was added to a final concentration of $25 \mu \mathrm{g} / \mathrm{ml}$ immediately after preparation of PA spheroplasts or PEG spheroplasts.

Transfection assay. For transfection, $0.4 \mathrm{ml}$ of spheroplasts was added to $0.4 \mathrm{ml}$ of DNA solution in $0.05 \mathrm{M}$ Tris- $\mathrm{HCl}, \mathrm{pH} 8.1$. After incubation for $15 \mathrm{~min}$ at $30^{\circ} \mathrm{C}, 3.2 \mathrm{ml}$ of PAM medium, ${ }^{112}$ prewarmed to $30^{\circ} \mathrm{C}$, was added. The mixture was incubated for $120 \mathrm{~min}$ at $30^{\circ} \mathrm{C}$. The yield of mature phage was assayed after disruption of spheroplasts with chloroform.

\section{RESULTS}

Effect of PEG on transfection with $\phi X 174$ ss DNA

When PEG was used instead of sucrose as an osmotic stabilizer, the efficiency of transfection with $\phi \times 174$ ss DNA increased about 4.7-fold at lower concentrations of PEG (Fig. 1). Optimal concentration of PEG was 0.5 to $1.0 \%$. At high concentrations of PEG, transfection with $\phi \times 174$ ss DNA was inhibited.

\section{Effect of DNA concentration}

Figure 2 shows a relationship between $\phi \times 174$ ss DNA concentration and the yield of mature phage in transfection in both PA spheroplasts and PEG spheroplasts. In both spheroplasts, the yield of mature phage was proportional to a wide range of $\phi \mathrm{X} 174$ ss DNA concentrations. Above $3.7 \times 10^{9}$ DNA molecules/ml transfection was saturated. These results were co-

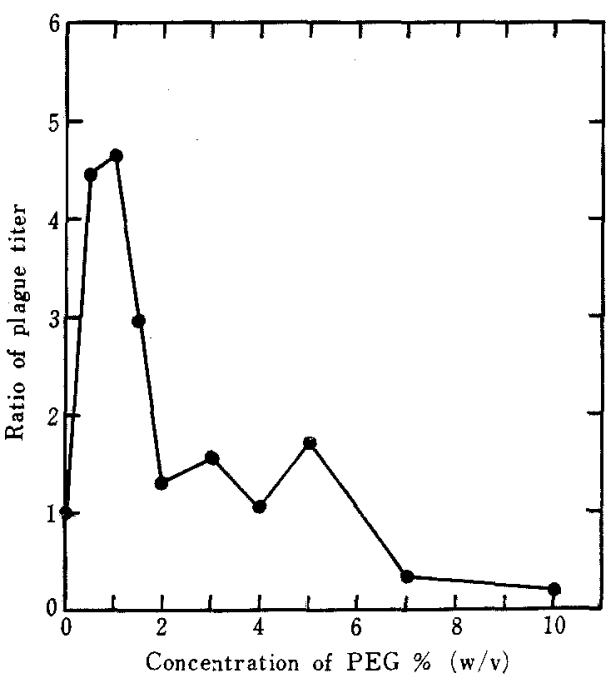

Fig. 1. Effect of PEG on Transfection with $\rho \times 174$ ss DNA.

PEG spheroplasts for various concentrations of PEG were prepared as described in Materials AND METHODS and assayed for the competence with $\phi \mathrm{X} 174$ ss DNA. The value of PEG concentration zero indicates the competence level of PA spheroplasts. Ratio of plaque titer 1 equivalents to $6.0 \times 10^{8}$ plaque forming units $/ \mathrm{ml}$.

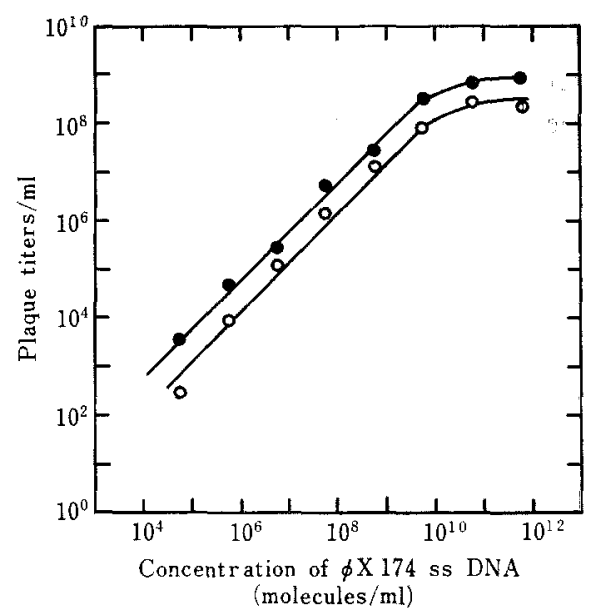

FIG. 2. Dependence of the Yield of Mature Phage on $\phi$ X174 ss DNA Concentration.

PA spheroplasts and 1\% PEG spheroplasts were prepared and assayed for the competence with various concentrations of $\phi \times 174$ ss DNA as described in Materials and Methods.

-—, $1 \%$ PEG spheroplasts; O—O, PA spheroplasts.

sistent with earlier reports. ${ }^{1,11}$ Figure 2 also indicated that the efficiency of transfection of 
PEG spheroplasts was higher than that of PA spheroplasts at any concentration of DNA.

\section{Effect of PEG on transfection with $\phi X 174$ $R F D N A$}

Benzinger et al. ${ }^{3,6)}$ have reported that transfection with $\phi \mathrm{X} 174 \mathrm{RF}$ DNA is stimulated by protamine sulfate. This stimulation by protamine sulfate was also confirmed in our experiments (see Fig. 4). Therefore, in the presence of protamine sulfate, the effect of PEG on transfection with $\phi \mathrm{X} 174 \mathrm{RF}$ DNA was examined. As shown in Fig. 3, transfection with $\phi \mathrm{X} 174 \mathrm{RF}$ DNA was further stimulated by $\mathrm{PEG}$ in the presence of protamine sulfate. Optimal concentration of PEG was 1.0 to $2.0 \%$ and the efficiency to transfection with $\phi \times 174$ RF DNA increased about 6.7fold. Sub-optimal concentration of PEG was

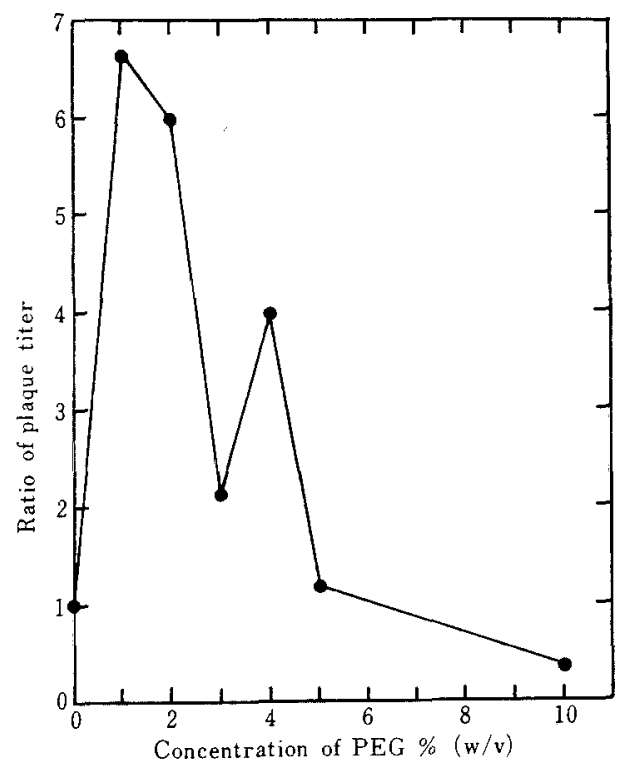

FIG. 3. Effect of PEG Concentration on Transfection with $\phi X 174$ RF DNA.

PEG spheroplasts for various concentrations of $P E G$ were prepared as described in Materials AND Methods. Protamine sulfate $(10 \mathrm{mg} / \mathrm{ml}$ in $0.05 \mathrm{M}$ Tris-HCl-0.5 $\mathrm{M} \mathrm{NaCl}, \mathrm{pH} 8.0$ ) was added to a final concentration of $25 \mu \mathrm{g} / \mathrm{ml}$ immediately after preparation of PEG spheroplasts. The competence of the spheroplasts was assayed with $\phi \times 174$ RF DNA as described in MATERIaLs AND Methods. The value of PEG concentration zero indicates that of PA spheroplasts containing $25 \mu \mathrm{g} / \mathrm{ml}$ protamine sulfate. observed at $4 \%$ in some experiments. At high concentrations of PEG, transfection with $\phi \mathrm{X} 174 \mathrm{RF}$ DNA was inhibited as well as with $\phi \mathrm{X} 174$ ss DNA. Optimal concentration of PEA was $2 \%$ even in the presence of protamine sulfate (data not shown). The linear relationship between the yield of mature phage and $\phi \mathrm{X} 174 \mathrm{RF}$ DNA concentration in transfection was also observed (data not shown).

\section{Stability of PEG spheroplasts containing pro- tamine sulfate}

Figure 4 presents the data on the stability of various spheroplasts. The level of the competence in PEG spheroplasts and PA spheroplasts containing protamine sulfate generally increased until $24 \mathrm{hr}$ after preparation and

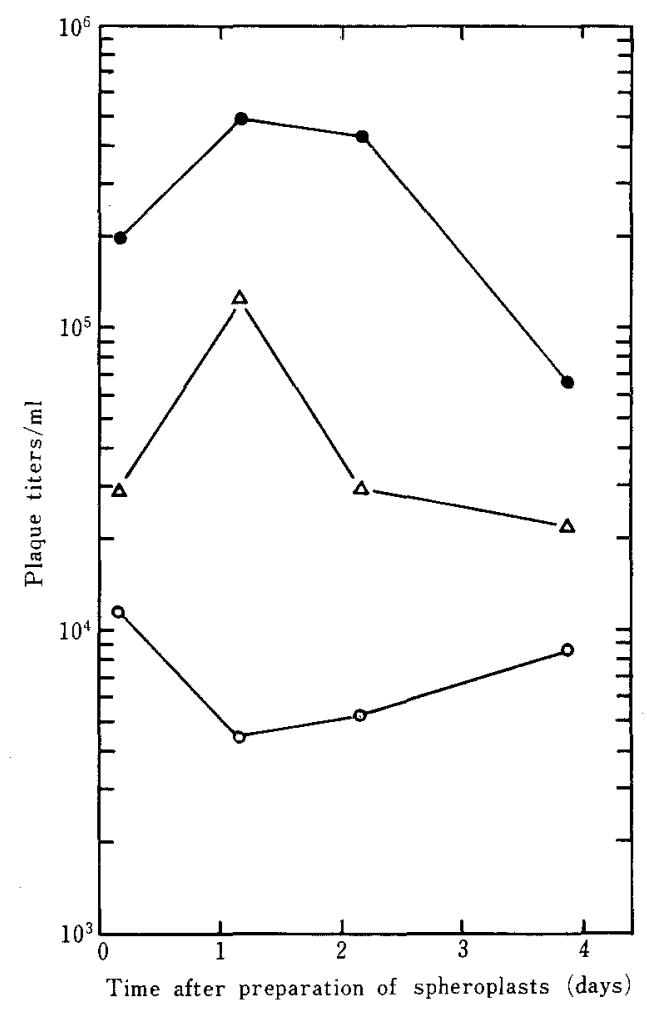

FIG. 4. Stability of the Competence Level.

Spheroplasts were prepared as described in Fig. 3 and stored at $0^{\circ} \mathrm{C}$. The competence with $\phi$ X174 RF DNA was tested $3 \mathrm{hr}$ later and further at the times indicated on the abscissa.

$\bigcirc-O$, PA spheroplasts; $\triangle-\triangle$, PA spheroplasts containing $25 \mu \mathrm{g} / \mathrm{ml}$ protamine sulfate; $-0,1 \%$ PEG spheroplasts containing $25 \mu \mathrm{g} / \mathrm{ml}$ protamine sulfate. 
gradually decreased. The competence level of PA spheroplasts was approximately constant for 4-days after preparation. However, in some preparations, PA spheroplasts were relatively labile and the competence level rapidly decreased within several hours. Figure 4 also indicated that protamine sulfate stimulated transfection with $\phi \mathrm{X} 174 \mathrm{RF}$ DNA and that further stimulation of transfection with $\phi \mathrm{X} 174$ RF DNA at any time.

\section{DISCUSSION}

The efficiency of transfection with $\phi \mathrm{X} 174$ ss DNA and RF DNA increased by using PEG as an osmotic stabilizer instead of sucrose. Optimal concentration of PEG differs from $\phi \mathrm{X} 174$ ss DNA and RF DNA (Figs. 1 and 3). Melechen et al. ${ }^{8 i}$ have reported that the highest efficiency for $\lambda$ DNA is observed at a PEG concentration of $8 \%$. At this concentration of PEG, transfection with $\phi \mathrm{X} 174$ ss DNA and RF DNA is inhibited (Figs. 1 and 3). It is considered that optimal concentration of PEG depends on molecular size of DNA used. The reason that transfection with $\phi \times 174$ is inhibited at high concentrations of PEG is unknown, though a similar inhibition of transfection by high concentrations of sucrose has been reported. ${ }^{15)}$

The effect of PEG on transfection is independent of protamine sulfate. Protamine sulfate stimulates transfection with doublestranded DNA (Fig. 4), but inhibits that with single-stranded DNA. ${ }^{33}$ However, optimal concentration of PEG for $\phi \mathrm{X} 174 \mathrm{RF}$ DNA in the presence of protamine sulfate is the same as that in the absence of protamine sulfate. Furthermore, PEG stimulates transfection with $\phi \mathrm{X} 174$ ss DNA as well as RF DNA even in the presence of protamine sulfate. The increasing of the competence of spheroplasts containing protamine sulfate is observed. The result is consistent with earlier report. ${ }^{8 \text { ) }}$

The mechanism of increasing the efficiency of transfection is unclear. Reaveley et al. ${ }^{16)}$ have reported that PEG 600 prevents much effectively leakage of macromolecules in pro- toplasts of Bacillus licheniformis. As described by Melechen et $a l .{ }^{8)}$ PEG protects spheroplasts for mechanical forces. Actually, it is observed that the competence of PEG spheroplasts is maintained after shearing the spheroplasts with a thermo-mixer and PEG spheroplasts are easier to handle than PA spheroplasts, which are labile for mechanical forces. It is considered that PEG protects spheroplasts from disruption or lysis and decreases the amount of bacterial macromolecules, which interfere transfection, ${ }^{11}$ released from their lysed cells.

Since PEG induces cell fusion of protoplasts of Penicillium chrysogenum ${ }^{17}$ or plant cells, ${ }^{18}$, PEG may act the cell membrane of $E$. coli spheroplasts to be more permeable for DNA and increase the ability of the competence of spheroplasts.

Since PEG spheroplasts have high transfection efficiency for both double-stranded DNA and single-stranded DNA, and are more stable than PA spheroplasts, that transfection of PEG spheroplasts is a useful technique for assaying the biological activity of viral nucleic acid.

Acknowledgement. This work was in part supported by a scientific grant of Ministry of Education Japan.

\section{REFERENCES}

1) R. L. Sinsheimer, "Methods in Enzymology," Vol. XII part B, ed. by L. Grossman and K. Moldave, Academic Press Inc., New York, 1968, p. 850 .

2) T.A. Trautner and H.Ch. Spatz, Curr, Top.Microbiol. Immunol., 62, 61 (1973).

3) R. Benzinger, I. Kleber and R. Huskey, J. Virol., 7, 646 (1971).

4) H. Osowiecki and B. A. Skalińska, Mol. Gen. Genet., 133, 335 (1974).

5) E. T. Young and R. L. Sinsheimer, J. Mol. Biol., 30, 147 (1967).

6) W. D. Henner, I. Kleber and R. Benzinger, $J$. Virol., 12, 741 (1973).

7) C. R. Merril and M. Geier, Virology, 42, 780 (1970).

8) N. E. Melechen, T. A. Hudnik-Plevnik and G. S. Pfeifer, ibid., 47, 610 (1972).

9) R. L. Sinsheimer, J. Mol. Biol., 1, 37 (1959).

10) R. M. Benbow, C. A. Hutchison III, J. D. Fabricant and R. L. Sinsheimer, J. Virol., 7, 549 (1971). 
11) G. D. Guthrie and R. L. Sinsheimer, Biochim. Biophys. Acta, 72, 290 (1963).

12) R. L. Sinsheimer, "Procedures in Nucleic Acid Research," ed. by G. L. Cantoni and D.R. Davis, Harper and Row, Publishers, New York, N.Y., 1966, pp. 569.

13) K. R. Yamamoto and B. M. Alberts, Virology, 40, 734 (1970).

14) T. Komano and R. L. Sinsheimer, Biochim. Bio- phys. Acta, 155, 295 (1968).

15) T. Fujiwara and T. Komano, Agric. Biol. Chem., 38, 2281 (1974).

16) D. A. Reaveley and H. J. Rogers, Biochem. $I$, 113, 67 (1969).

17) J. Anne and J. F. Peberdy, Arch. Microbiol., 105, 201 (1975).

18) K. N. Kao and M. R. Michayluk, Planta, 115, 355 (1974). 